Maike Wiesenfarth assembles solar cell components at the Fraunhofer Institute for Solar Energy Systems.

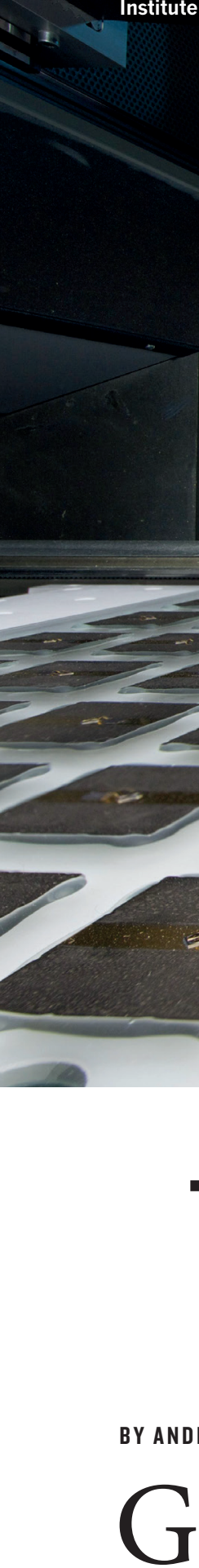

TIME TO RENEW THE ENERGY EXPERIMENT

The pioneer in sustainability faces competition abroad and public opposition at home. agenda and high levels of public funding. The result has been a wealth of opportunities for scientists working in the private and public sector. The renewable-energy field employs nearly 340,000 people in Germany, and according to the Federal Ministry for Education and Research (BMBF), there are now more than 180 universities and 120 research institutes involved in the country's energytransition programme, Energiewende.
However, over the past decade, Germany's renewables industry has been challenged by strong competition from elsewhere in the world. Its once-dominant solar-panelmanufacturing industry, for example, has largely been gutted by cheaper competitors in Asia (see 'Top 10 solar-cell producers in 2016'). The impact has rippled beyond industry to laboratories around Germany, causing many scientists to re-evaluate their study priorities and career plans. "That affected research," says Eva Unger, a chemist at the Helmholtz-Center Berlin for Materials and Energy. "There's a sense that we should get out of solar and do something else."
The government's response has been to substantially increase the annual funding for renewable-energy research. In its energy plan for 2013, the German federal government announced investment of $€ 400$ million (US $\$ 459$ million) per year in renewables research, on top of the contribution of individual states to research projects and universities. In 2017, funding for energy efficiency and renewables research increased to $€ 800$ million, which is being funnelled into projects aimed at better integrating renewable energy into the existing energy system, research organizations such as the Helmholtz Association, and large-scale grant programmes such as the 
Kopernikus Projects. The federal government also announced it would increase spending on its energy-research programme, which began in the 1970s to promote the research of nonnuclear technologies, to $€ 6.4$ billion between 2018 and 2022, an increase of $45 \%$ compared with the previous five-year period.

"Funding levels are continually climbing," says Niklas Martin, head of the German Renewable Energy Research Association in Berlin. "You can count on funding when it comes to planning a career."

\section{"IT'S NO LONGER ENOUGH TO FOCUS ON TECHNOLOGY."}

The Energiewende's most ambitious goal generating $80 \%$ of the country's power from renewables by 2050 - was set in 2010 . After the release of radioactive material at Japan's Fukushima Daiichi nuclear power plant following a tsunami in 2011, the shift took on a new urgency: German Chancellor Angela Merkel declared a complete nuclear pull-out, meaning Germany couldn't rely on nuclear power as part of its emissions-reduction plans. With nuclear energy off the table, policymakers and academics realized that achieving the emissions-reduction targets required major investments in energy research. The funding fuelled a boom in manufacturing capacity and innovation - between 2000 and 2013, Germany ranked third in the world in patent filings for renewable-energy technologies, behind China and the United States.

\section{INTEGRATION OF GREEN ENERGY}

There is still a lot of work to be done when it comes to encouraging societal adoption of renewable energy and support from businesses, and research priorities in Germany have changed to reflect a new phase of the transition. "It's no longer enough to focus on technology," says Tobias Sontheimer, chief research manager for energy at the Helmholtz Association in Berlin. The priority now, he says, is understanding the larger picture: how will Germany weave proven renewable-energy technology into a coordinated network capable of supplying industry and society with reliable power? The country's grid system and storage capacities in particular need to be overhauled
TOP IO SOLAR-GELL
PRODURERS IN 2016

Asia's photovoltaics manufacturing

companies dominate the global market.

1 HANWHA Q-CELLS SOUTH KOREA

2 JASOLAR MAINLAND CHINA

3 TRINA SOLAR MAINLAND CHINA

4 FIRST SOLAR UNITED STATES

5 JINKOSOLAR MAINLAND CHINA

6 MOTECH TAIWAN

7 TONGWEI SOLAR MAINLAND CHINA

8 YINGLI SOLAR MAINLAND CHINA

9 CANADIAN SOLAR CANADA*

10 SHUNGFENG GROUP MAINLAND CHINA

"manufacturing base in mainland China

to accommodate fresh forms of energy generation.

Research priorities and funding reflect this updated reality. Solar, for example, used to be a vibrant sector. Although there is still funding for cutting-edge solar research (see 'The second coming of solar'), investment is increasingly being targeted at battery and storage technologies to stabilize fickle solar- and windpower flows. And the biggest investments have been in projects that emphasize cross-sector collaboration. "Topics like how do we integrate technologies and sector coupling are gaining more and more attention," says Verena Fluri, an energy-systems analyst at the Fraunhofer Institute for Solar Energy Systems in Freiburg.

In a move that recognizes the challenges to come, the BMBF announced a major federal initiative, the Kopernikus Projects, in 2016. The four projects constitute the largest renewables research initiative Germany has ever seen. Between now and 2025, the government will invest $€ 400$ million in projects covering energy storage, the development of a power network designed around renewables, the adaptation of industrial processes to fluctuating renewable sources such as solar and wind, and the integration of conventional and renewable energy production. In a departure from the usual funding structure, the projects each involve dozens of partners, with an emphasis on bringing scientists together with industry groups, private companies and civil society to guarantee buy-in from the public. One of the projects, for example, joins 18 research institutions, 27 industrial companies and 3 civil-society bodies together to work on the problem of converting intermittent renewable electricity to hydrogen or other chemicals as a storage solution.

\section{WORKING TOGETHER}

Even political scientists and sociologists are finding a place in German renewables research. The Energiewende has been expensive, adding an estimated $€ 25$ billion each year to Germany's electricity bills. More than 1.6 million solar cells have sprouted on roofs and in fields across Germany, while wind turbines have become a common feature on the landscape - and not everyone is happy with the transformation. "We're starting to see scepticism from the population, particularly regarding wind power and high-voltage transmission lines," says Hans-Martin Henning, director of the Fraunhofer Institute for Solar Energy Systems. "When it comes to implementation, people see it's got impacts, it's not all green and beauty."

As a result, research institutes that once focused on scientific and technological questions are adding economic analysis and 'acceptance research' to their portfolios, hoping to understand how to incentivize businesses to adopt green energy and shape public opinion of the energy transition.

The Fraunhofer's solar-energy research

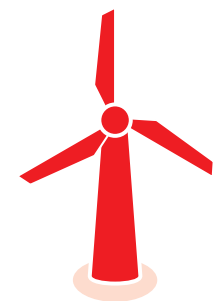

GERMAN CITIZENS PRIVATELY OWN A THIRD OF THE COUNTRY'S CAPACITY TO PRODUCE ELECTRICITY FROM RENEWABLE ENERGY SOURCES.

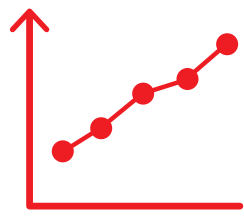

"FUNDING LEVELS ARE CONTINUALLY CLIMBING - YOU CAN COUNT ON FUNDING WHEN IT COMES TO PLANNING A CAREER." 
institute has been at the centre of this transformation. With almost 1,200 employees, it sits at the intersection of applied science and industry, carrying out research with a mixture of public and private funding. Henning argues that federal funding alone isn't enough to create a sustainable renewables-research sector — and that policymakers and academics need to make sure they retain the support of the public and Germany's business sector.

\section{"THERE'S A SENSE THAT WE SHOULD GET OUT OF SOLAR AND DO SOMETHING ELSE."}

Photovoltaic (PV) solar panels are a good example: government support put the country at the forefront of PV research, but low-cost manufacturing eventually drove PV-panel makers elsewhere. Henning worries that German investments in battery research and other areas could face a similar fate if politicians aren't careful. "In PV we were leading, and others took over," Henning says. "The research and development budget is still there, but how long can we keep it if we don't have local production and markets?"

\section{MODEL FOR FUTURE POWER}

Fluri is one of the researchers at the forefront of this more-integrated approach. At the lab where she works in Freiburg, she uses computer models to determine the best combination of technologies for reaching Germany's goals for renewable power. She says that the fundamental questions have changed as the lab, founded in 2009, has grown to more than a dozen researchers. "At first, the question was 'can we supply Germany with renewable energy?"” says Fluri. "Now there are more and more questions around how can we integrate it and what business models will support it."

That's why the models Fluri builds incorporate public opinion-survey data gathered by sociologists, and why her degree combined engineering know-how with economics. When it comes to the Energiewende, "it's important to understand the socio-economic aspects, too," she says. "Is it economically viable to build a PV battery system on an apartment building, for example? Are people willing to invest even at a lower rate of return?"

As the Energiewende matures, the research driving it will, too. "There's an understanding that we still need individual technologies," says Sontheimer. "At the same time, one of the big challenges of the future is bringing all these technologies which are being investigated together into a system and make it work." -

Andrew Curry is a journalist in Berlin.

\title{
PROFILE THE SECOND COMING OF SOLAR
}

\author{
Lured back to Germany by funding opportunities, Eva Unger thinks \\ that the country's solar-cell research could be entering a boom period.
}

Unger was born in Germany, but did most of her scientific training elsewhere, including a PhD at Uppsala University in Sweden and postdoctoral research at Stanford University in California. When the opportunity to pursue solar-cell research back home came up in 2016, she had her doubts — Germany's solar industry was struggling, and she already has a tenure-track position in Sweden.

In 2016, she moved to Berlin with funding from the German Ministry for Education and Research (BMBF) as part of its Helmholtz Innovation Lab initiative, a programme designed to provide lab infrastructure to young researchers to jump-start their work. (She still has a tenure-track position at Uppsala University.)

One year later, Unger's BMBF-funded laboratory at the Helmholtz-Center Berlin for Materials and Energy was up and running. And Unger says that the country's solarcell research future is bright thanks to the discovery of substances that yield even better returns from the Sun's rays when integrated with traditional photovoltaic (PV) materials.

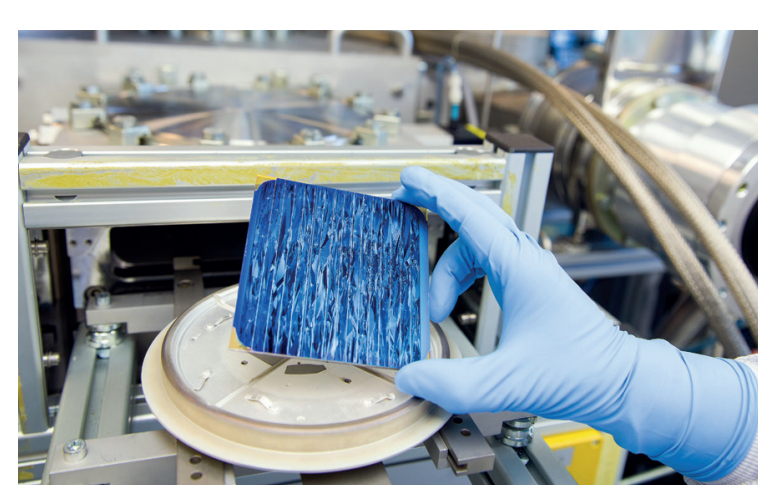

Eva Unger's group work on new photovoltaic materials such as

metal-halide perovskites.

Some of the most promising materials are perovskites, crystalline substances that combine organic and inorganic materials. Since they were first successfully used to convert light into electricity in 2009, researchers have shown that perovskites are among the most efficient candidates for the PV cells of the future. "Perovskites are the biggest hype in solar energy research right now," Unger says.

So far, however, their high yields have only been seen in experimental applications across small surfaces of 1 centimetre or less. Unger is focused on transforming their theoretical potential into real-world technology for converting solar energy into electricity. "One of the tasks is figuring out how we scale from $23 \%$ efficiency at less than 1 centimetre to 1 metre," she says.

In Berlin, Unger shares the all-purpose lab with two colleagues who are tackling issues that are equally crucial to deploying perovskites in the real world, such as how to keep the substances stable and integrate them with more conventional silicon-based solar-cell technologies.

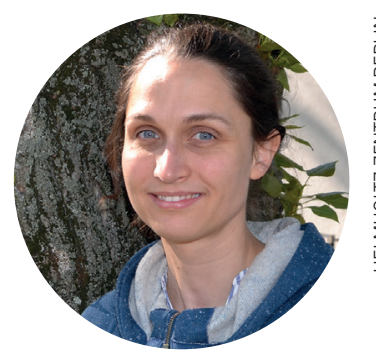

"WITH THE KNOWHOW WE HAVE, WE CAN ANSWER A LOT OF QUESTIONS WHEN IT COMES TO NEW MATERIALS."

The Innovation Lab is also intended to connect young researchers with corporate partners, a departure for the academicresearch-oriented Helmholtz Association. "It's helping me really understand what the important parameters are in terms of whether the material will work as a device in the future," says Unger.

And to her surprise, even the crash of Germany's once-vaunted solar industry seems to have a silver lining. Start-up firms focused on using next-generation materials in solar arrays have begun returning to Berlin-area factories that were emptied out by a wave of bankruptcies. And there are lots of well-trained engineers with solar-cell experience based in Germany. "Sure, the German PV industry declined, but the facilities and expertise are still there," she says. "With the knowhow we have, we can answer a lot of questions when it comes to new materials." A.C. 